University of Nebraska - Lincoln

DigitalCommons@University of Nebraska - Lincoln

Mammalogy Papers: University of Nebraska

State Museum

Museum, University of Nebraska State

January 1970

\title{
Bats of the Genus Myotis from Western Mexico, with a Key to Species
}

J. Knox Jones Jr.

The University of Kansas, Lawrence

Hugh H. Genoways

The University of Kansas, Lawrence, h.h.genoways@gmail.com

Larry C. Watkins

The University of Kansas, Lawrence

Follow this and additional works at: https://digitalcommons.unl.edu/museummammalogy

Part of the Zoology Commons

Knox Jones, J. Jr.; Genoways, Hugh H.; and Watkins, Larry C., "Bats of the Genus Myotis from Western Mexico, with a Key to Species" (1970). Mammalogy Papers: University of Nebraska State Museum. 64. https://digitalcommons.unl.edu/museummammalogy/64

This Article is brought to you for free and open access by the Museum, University of Nebraska State at DigitalCommons@University of Nebraska - Lincoln. It has been accepted for inclusion in Mammalogy Papers: University of Nebraska State Museum by an authorized administrator of DigitalCommons@University of Nebraska Lincoln. 


\section{Transactions}

of the

\section{Kansas Academy of Science}

Published Quarterly by the

Kansas ACAdemy of SCIENCE (Founded 1868)

OFFICERS

Margaret Parker, President

K.S.C., Pittsburg

JERRY S. WeIs, Secretary

K.S.U., Manhattan

LETHA DRYDEN, Treasure,

Hays

Laurence R. Draper, Editor

K.U., Lawrence

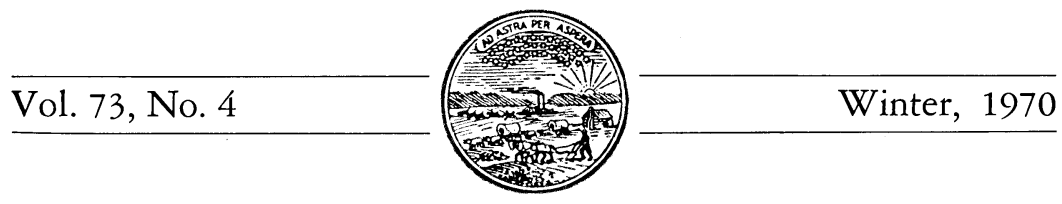

Bats of the Genus Myotis from Western Mexico, with a Key to Species

J. KNOX JONES, JR., HUGH H. GENOWAYS, and LARRY C. WATKINS

Museum of Natural History, The University of Kansas, Lawrence

Distribution and variation in Mexican representatives of the vespertilionid bat genus Myotis have not been well documented. The most complete modern systematic treatment of these bats is that of Miller and Allen (1928), although these authors examined relatively few specimens and some of their taxonomic conclusions have been modified by more recent studies (see especially Findley, 1960; Findley and Jones, 1967; Genoways and Jones, 1969). In the past two decades, field representatives of the Museum of Natural History at The University of Kansas have obtained large collections of mammals in western México, principally in the states of Jalisco and Sinaloa. Bats of eight species of Myotis are among the specimens thus obtained, and we here summarize pertinent ecologic, taxonomic, and distributional data relative to these taxa. Also provided is a key to members of the genus on the mainland of western México, which it is hoped will prove useful for field recognition of the included species.

Transactions of the Kansas Academy of Science, Vol. 73, No. 4, 1970. Published July 28, 1971. 
In addition to our own field work, J. R. Alcorn, R. H. Baker and students who accompanied him, P. L. Clifton, W. L. Cutter, R. F. Johnston and students, and M. R. Lee obtained specimens used in this report. Field work has been sponsored by the Museum of Natural History and Department of Zoology at Kansas, the Kansas University Endowment Association, the University's Committee on Systematic and Evolutionary Biology (NSF grant GB-4446X1), and through a contract (DA-49-193-MD-2215) with the Medical Research and Development Command of the U. S. Army.

In the following accounts, all catalogue numbers refer to the collections of the Museum of Natural History of The University of Kansas. All measurements are given in millimeters and all weights are in grams. External measurements are listed in the following sequence: total length; length of tail; length of hind foot; length of ear; and length of forearm.

Myotis auriculus apache Hoffmeister and Krutzsch, 1955

Specimens examined.-JALISCO: $4 \mathrm{~km}$. E Venustiano Carranza, 2160 meters, $10 \mathrm{mi}$. NNE Pihuamo, $3500 \mathrm{ft} ., 1$.

Only three specimens of this bat are known from Jalisco-one from Los Masos (Findley, 1960:20) and the two herein reported.

A male from $4 \mathrm{~km}$. E Venustiano Carranza was taken at 10:37 PM from a net stretched across a dry stream bed under a large, overhanging tree. Coniferous forest grew on a hillside in one direction from the stream bed and a large, heavily grazed field was adjacent on the other. Several Myotis velifer had been taken earlier in the same net and the auriculus evidently was attracted to the net by the squeeking of a handheld $M$. velifer. A female from $10 \mathrm{mi}$. NNE Pihuamo was netted over a small stream, which was lined with trees that formed a complete canopy over it.

External measurements of our two specimens (male first) are: 87, 88; $38,39.5 ; 10,10.5 ; 19,20 ; 39.5,39.7$. The male weighed 6.2 (testes, $4.0)$ and is somewhat darker in color of pelage and membranes than the female. Genoways and Jones (1969) recently have discussed reasons for use of the specific name auriculus for this bat, formerly regarded (Findley, 1960) as a representative of Myotis keenii.

\section{Myotis californicus mexicanus (Saussure, 1860)}

Specimens examined.-SINALOA: $5 \mathrm{mi}$. E Plomosas, $5500 \mathrm{ft}$., 2; $3 \mathrm{mi}$. SE Plomosas, $4000 \mathrm{ft}$., 1 . JALISCO: $10 \mathrm{mi}$. N Guadalajara, $3350 \mathrm{ft}$., 1; $2 \mathrm{mi}$. SE Mascota, $5200 \mathrm{ft}$., 1; Sierra de Cuale, $7300 \mathrm{ft} ., 1 ; 5 \mathrm{mi}$. W Atenquique, $7700 \mathrm{ft}$., 1; Volcán de Fuego, 9800 ft., 1.

This dark-colored subspecies of $M$. californicus inhabits mountainous areas of south-central México, from Tamaulipas and Veracruz 
westward to Sinaloa and Guerrero. All of our specimens are from elevations of 3350 feet or higher. M. c. mexicanus has been reported previously from Jalisco by Miller and Allen (1928:160) from Los Masos, Santa Rosalia, and Sierra Nevada de Colima, and Genoways and Jones (1967:477-478) mentioned in passing two of the Jaliscan specimens here listed. The three bats from the vicinity of Plomosas, in southeastern Sinaloa, netted or shot in pine-oak forest, are the first to be reported from that state. Most of our Jaliscan specimens were netted or shot in pineoak forest or pine-oak mixed with fir. The one from north of Guadalajara was shot from a night roost in a culvert in the barranca of the Rio Grande de Santiago in an area where the vegetation was predominantly tropical in nature.

A Sinaloan female (30 April 1965) carried a single embryo that measured 10 (crown-rump). A male from Sierra de Cuale (26 October 1962) had testes that measured 3.5 in length.

External measurements of two females from Sinaloa, followed by those of a female and two males from Jalisco, are, respectively: 81, 78, $77,75,87 ; 35,34,36,35,37 ; 7,7,7,7,8 ; 14,14.5,14,14,13 ; 34.4$, 33.1, 32.8, 32.0, 33.2. The Sinaloan females both weighed 4.6.

Myotis fortidens fortidens Miller and Allen, 1928

Specimens examined.-SINALOA: Cosalá, $1300 \mathrm{ft}$., 1; $6 \mathrm{~km}$. E Cosalá, 1500 ft., 3; Isla Palmito de la Virgen, $15 \mathrm{ft}$., 3. JALISCO: El Tabaco, $200 \mathrm{ft}$., 6.

Aside from the specimens here listed, $M . f$. fortidens is known from Sinaloa only from Escuinapa (Hall and Dalquest, 1950:587), and our series from Jalisco represents the first record of the species for that state. Findley and Jones (1967:442) have recorded fortidens from several localities in western México. The material at hand confirms their conclusion that the subspecies fortidens is smaller and more brightly colored than is sonoriensis, and that fortidens occurs at least as far north as central Sinaloa.

Specimens from the vicinity of Cosalá, Sinaloa, all were taken in mist nets set over streams; those from the barrier island of Palmito de la Virgen were netted over a freshwater pond approximately 50 yards in diameter along with Noctilio leporinus and Rhogeessa parvula. The Jaliscan series, all males, was netted along pathways cut through a dense, old banana grove. Many phyllostomatids, Pteronotus parnellii, and Lasiurus ega were taken in the same nets. Four of five June-taken females from Sinaloa were pregnant; embryos measured 4, 7, 10, and 12 in crown-rump length.

External measurements of three females and a male, respectively, from the vicinity of Cosalá, Sinaloa, followed by the average and extreme 
Table 1. Cranial measurements of eight species of Myotis from western México.

\begin{tabular}{|c|c|c|c|c|c|c|c|}
\hline $\begin{array}{l}\text { Number averaged } \\
\text { or catalogue } \\
\text { number, and sex }\end{array}$ & 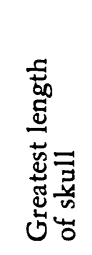 & 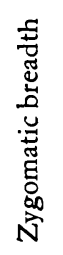 & 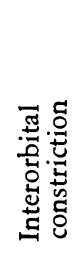 & 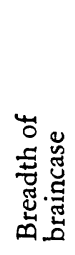 & 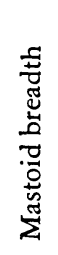 & 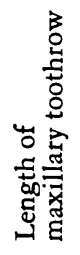 & 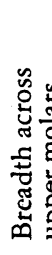 \\
\hline \multicolumn{8}{|c|}{ Myotis auriculus apache, Jalisco } \\
\hline $\begin{array}{l}\text { KU 120509, } \\
\text { KU 108607, 운 }\end{array}$ & $\begin{array}{l}16.5 \\
17.0\end{array}$ & $\begin{array}{r}9.8 \\
10.3\end{array}$ & $\begin{array}{l}3.7 \\
3.8\end{array}$ & $\begin{array}{l}7.7 \\
7.9\end{array}$ & $\begin{array}{l}8.4 \\
8.6\end{array}$ & $\begin{array}{l}6.6 \\
6.6\end{array}$ & $\begin{array}{l}6.4 \\
6.5\end{array}$ \\
\hline \multicolumn{8}{|c|}{ Myotis californicus mexicanus, $5 \mathrm{mi}$. E Plomosas, Sinaloa } \\
\hline $\begin{array}{l}\mathrm{KU} 97051,9 \\
\mathrm{KU} 97052, q\end{array}$ & $\begin{array}{l}14.3 \\
13.6\end{array}$ & $\begin{array}{l}8.1 \\
8.4\end{array}$ & $\begin{array}{l}3.0 \\
3.3\end{array}$ & $\begin{array}{l}6.1 \\
6.4\end{array}$ & $\begin{array}{l}6.9 \\
\cdots\end{array}$ & $\begin{array}{l}5.5 \\
5.3\end{array}$ & $\begin{array}{l}5.5 \\
5.5\end{array}$ \\
\hline \multicolumn{8}{|c|}{ Jalisco } \\
\hline $\begin{array}{l}\text { KU 92945, के } \\
\text { KU 107485, 혀 } \\
\text { KU 103651, ᄋ }\end{array}$ & $\begin{array}{l}13.8 \\
14.2 \\
13.6\end{array}$ & $\begin{array}{l}8.3 \\
8.6 \\
8.3\end{array}$ & $\begin{array}{l}3.2 \\
3.1\end{array}$ & $\begin{array}{l}6.3 \\
6.5 \\
6.4\end{array}$ & $\begin{array}{l}6.9 \\
7.1 \\
6.9\end{array}$ & $\begin{array}{l}5.1 \\
5.3 \\
5.1\end{array}$ & $\begin{array}{l}5.4 \\
5.2 \\
5.3\end{array}$ \\
\hline
\end{tabular}

Myotis fortidens fortidens, $6 \mathrm{~km}$. E Cosalá, Sinaloa

\begin{tabular}{|c|c|c|c|c|c|c|c|}
\hline KU 90734, 9 & 15.1 & $\ldots$. & 4.0 & 7.3 & 7.8 & 5.7 & 6.2 \\
\hline KU 90735, 우 & 14.8 & 9.2 & 3.7 & 6.9 & 7.5 & 5.6 & 6.0 \\
\hline \multicolumn{8}{|c|}{ El Tabaco, Jalisco } \\
\hline Average $6(\hat{o})$ & 15.0 & 9.7 & 3.9 & 7.2 & 7.8 & 5.7 & 6.3 \\
\hline Minimum & 14.4 & 9.5 & 3.8 & 6.9 & 7.5 & 5.5 & 6.1 \\
\hline Maximum & 15.7 & 10.1 & 4.1 & 7.4 & 8.1 & 5.9 & 6.6 \\
\hline \multicolumn{8}{|c|}{ Myotis fortidens sonoriensis, Río Fuerte, Sinaloa } \\
\hline KU 67491, ô & 16.0 & 10.5 & 3.8 & 7.5 & 8.2 & 6.0 & 6.6 \\
\hline \multicolumn{8}{|c|}{ Myotis nigricans extremus, Jalisco } \\
\hline Average $6(3 \hat{\delta}, 3 \%)$ & 13.8 & 8.3 & 3.4 & 6.5 & 7.0 & 5.3 & 5.5 \\
\hline Minimum & 13.7 & 8.2 & 3.3 & 6.5 & 6.7 & 5.1 & 5.4 \\
\hline Maximum & 14.0 & 8.5 & 3.5 & 6.7 & 7.2 & 5.5 & 5.7 \\
\hline
\end{tabular}

Myotis thysanodes thysanodes, $10 \mathrm{mi}$. SE Talpa de Allende, Jalisco

$\begin{array}{llllllll}\text { KU 97063, }+ & 16.4 & 10.4 & 4.1 & 7.8 & 8.3 & 6.3 & 6.4 \\ \text { KU 97064, }+ & 16.9 & 10.9 & 4.2 & 8.3 & 8.5 & 6.2 & 6.7\end{array}$

Myotis velifer velifer, vicinity Santa Lucía, Sinaloa

\begin{tabular}{|c|c|c|c|c|c|c|c|}
\hline & & & & & & & \\
\hline Average 20 ( $\%$ ) & 16.7 & 10.6 & 3.9 & 7.5 & 8.5 & 6.7 & 7.0 \\
\hline Minimum & 16.2 & 10.2 & 3.7 & 7.3 & 8.2 & 6.3 & 6.7 \\
\hline Maximum & 17.2 & 11.0 & 4.1 & 7.7 & 8.7 & 7.0 & 7.4 \\
\hline & vicin & Guad & ara, J & & & & \\
\hline Average $20(11 \hat{\delta}, 9 q)$ & 16.6 & 10.7 & 3.9 & 7.6 & 8.5 & 6.6 & 7.0 \\
\hline Minimum & 16.1 & 10.3 & 3.6 & 7.4 & 8.2 & 6.3 & 6.7 \\
\hline Maximum & 17.2 & 11.2 & 4.2 & 7.9 & 8.8 & 6.8 & 7.2 \\
\hline
\end{tabular}

Myotis volans amotus, $15 \mathrm{mi}$. S and $9 \mathrm{mi}$. E Talpa de Allende, Jalisco

$\begin{array}{llllllll}\text { KU 97066, } 9 & 14.1 & 8.4 & 3.6 & 7.1 & 7.5 & 5.4 & 5.5\end{array}$ 
Table 1. Continued.

\begin{tabular}{|c|c|c|c|c|c|c|c|}
\hline $\begin{array}{l}\text { Number averaged } \\
\text { or catalogue } \\
\text { number, and sex }\end{array}$ & 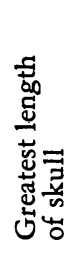 & 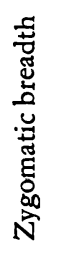 & 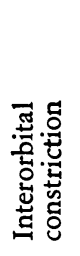 & 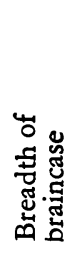 & 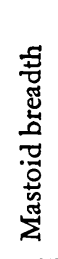 & 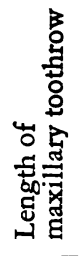 & 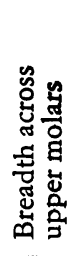 \\
\hline \multicolumn{8}{|c|}{ Myotis yumanensis lutosus, northern Sinaloa } \\
\hline KU 95174, ô & 13.0 & ... & 3.6 & 6.7 & 7.0 & 5.0 & 5.0 \\
\hline KU 95876, శ̊ & 13.4 & 8.1 & 3.6 & 6.6 & 7.0 & 4.9 & 5.1 \\
\hline KU 95877, ồ & 13.2 & $\ldots$ & 3.6 & 6.6 & 6.8 & 4.8 & 5.0 \\
\hline \multicolumn{8}{|c|}{ El Salto, Jalisco } \\
\hline Average $6(1 \hat{\circ}, 5 \uparrow)$ & 13.2 & 8.1 & 3.6 & 6.7 & 7.0 & 4.9 & 5.1 \\
\hline Minimum & 12.9 & 7.8 & 3.3 & 6.3 & 6.7 & 4.8 & 5.0 \\
\hline Maximum & 13.6 & 8.5 & 3.8 & 6.9 & 7.3 & 5.0 & 5.2 \\
\hline
\end{tabular}

measurements of the six Jaliscan males, are: $89,84,90,80,83.3$ (80$86)$; 35, 32, 37, 31, 34.1 (32.5-35); 9, 9, 10, 9, 8.9 (8-9.5); 14.5, 14.5, $15,14,13.5(12-15)$; 36.1, 35.2, 37.5, 37.6, 36.0 (34.7-38.8). Four Sinaloan specimens, two pregnant females, a nonpregnant female, and a male, weighed $6.0,7.5,7.0$, and 5.7 , respectively.

Myotis fortidens sonoriensis Findley and Jones, 1967

A male from the Río Fuerte, $1 \mathrm{mi}$. $\mathrm{N}$ and $1 / 2 \mathrm{mi}$. E San Miguel, in northern Sinaloa, is the only bat of this subspecies in our collections. Findley and Jones (1967:442) and Jones et al. (1962:154, as $M$. occultus) previously have reported on this same individual. External measurements of the specimen are 101, 44, 10, 13, 38.7, weight 8.0.

\section{Myotis nigricans extremus Miller and Allen, 1928}

Specimens examined.-JALISCO: $14 \mathrm{mi}$. WSW Ameca, $5000 \mathrm{ft} ., 1 ; 2 \mathrm{mi}$. S La Cuesta, $1500 \mathrm{ft}$., 1; Contla, 1320 meters, 1; $11 \mathrm{mi}$. SW Autlán, 710 meters, 1; ca. $30 \mathrm{~km}$. N, $10 \mathrm{~km}$. E Santiago (Colima), 1; $15 \mathrm{~km}$. NW Cihuatlán, 5.

This Neotropical species has been reported previously from Jalisco by Davis and Carter (1962:72), from $16 \mathrm{mi}$. NE Tamazula, and by Jones (1964:513) on the basis of several of the specimens here listed. $M$. nigricans is known from as far north in western México as the vicinity of San Blas, Nayarit (Gardner, 1962:103). All of our specimens were netted over ponds or streams. The one from the highest elevation (5000 feet) was the only bat taken in two nets stretched over a stream in a tropically-vegetated canyon situated between oak-covered hills. None of the females examined (April- and May-taken) was reproductively active. 
Average and extreme external measurements of nine adults (four males, five females) are as follows: 78.2 (74-83); $34.2(31-40) ; 7.9$ (7-9); 12.1 (11-13.5); 34.7 (33.0-36.9); seven specimens averaged $3.9(3.5-5.0)$ in weight.

Myotis thysanodes thysanodes Miller, 1897

Specimens examined.-JALISCO: $10 \mathrm{mi}$. SE Talpa de Allende, $5350 \mathrm{ft}$., 2.

Our two specimens were netted by Percy L. Clifton on 14 May 1964 between midnight and dawn over a pool in a mountain stream. Tall deciduous trees grew along the stream, whereas pine-oak forest clothed the surrounding hillsides. Other species netted along with $M$. thysanodes included Pteronotus parnellii, Glossophaga soricina, Enchistenes bartii, and Eptesicus fuscus. The fringed myotis has been reported previously from La Laguna and Los Masos, Jalisco, by Miller and Allen (1928:127); a specimen listed in the original description of the species (Miller, 1897:83) from Sierra Nevado de Colima is unaccounted for in subsequent publications.

Both bats were pregnant, each with a single embryo; the embryos measured 18 and 15 in crown-rump length. External measurements of the two females, which are darker in color than typical members of the subspecies, are: 92,$89 ; 37,32 ; 11,11 ; 18.5,19 ; 43.7$, 42.5; weight 8.6, 9.7.

Myotis velifer velifer (J. A. Allen, 1890)

Specimens examined.-SINALOA: $1 / 2 \mathrm{mi}$. SE Vaca, $650 \mathrm{ft} ., 1$; El Fuerte, 150 meters, 2; Río Fuerte, $1 \mathrm{mi}$. N, 1/2 mi. E San Miguel, 1; $10 \mathrm{mi}$. NNW Los Mochis, 1; La Cruz, $30 \mathrm{ft}$., 1; $1 \mathrm{~km}$. NE Santa Lucía, $3700 \mathrm{ft} ., 16$; Santa Lucía, $3600 \mathrm{ft}$., 4; $1 \mathrm{mi}$. E Santa Lucía, 5650 (=ca. 3650) ft., 52; $1 \mathrm{~km}$. NE Pánuco, $2700 \mathrm{ft}$., 1; $7 \mathrm{mi}$. ENE Plomosas, $6000 \mathrm{ft}$., 2; $3 \mathrm{mi}$. SE Plomosas, $4000 \mathrm{ft}$., 3.

JALISCO: $12 \mathrm{mi}$. W Encarnación de Díaz, $5600 \mathrm{ft}$., 5; $14 \mathrm{mi}$. SE Lagos de Moreno, $6700 \mathrm{ft} ., 1 ; 2 \mathrm{mi}$. NW Magdalena, $4500 \mathrm{ft}$., 1; $1 \mathrm{mi}$. NE Tala, $4400 \mathrm{ft}$., 1; $2 \mathrm{mi}$. SE Mascota, $5200 \mathrm{ft}$., 11; Atenguillo, 1; $13 \mathrm{mi}$. S, $15 \mathrm{mi}$. W Guadalajara, 21; $21 \mathrm{mi}$. SW Guadalajara, 11; Hda. San Martín, $5000 \mathrm{ft}$., $18 \mathrm{mi}$. W Chapala, 3; 15 mi. S, 9 mi. E Talpa de Allende, $6900 \mathrm{ft}$., 5; 4 mi. E Atemajac de Brizuela, $8000 \mathrm{ft} ., 1 ; 6 \mathrm{mi}$. E Limón, $2700 \mathrm{ft}$., 7; $5 \mathrm{mi}$. S Grullo, $3100 \mathrm{ft} ., 1 ; 6 \mathrm{mi}$. S Mazamitla, $6200 \mathrm{ft} ., 17 ; 3 \mathrm{~km}$. E Venustiano Carranza, 2130 meters, 1; $4 \mathrm{~km}$. E Venustiano Carranza, 2160 meters, 10; $4 \mathrm{~km}$. W Tuxpan, 1380 meters, 1.

The cave myotis is the commonest and most widespread member of the genus in western México, where it occurs in a variety of habitats from sea level in Sinaloa up to at least 8000 feet in Jalisco. We have seen no bats of this species from the coastal areas of the latter state. Many of our specimens were taken in mist nets, but other were shot in flight or captured in abandoned buildings. $M . v$. velifer has been reported previously from Sinaloa by Jones et al. (1962:154) and in passing by Hayward (1970:24). The subspecies originally was described from Jalisco (J. A. Allen, 1890:177) and has been recorded since by several 
authors-see especially Miller and Allen (1928:91) and Villa-R (1967: 367).

Among the females at hand, in which all months from February through October are represented, only individuals obtained in May, June, and July evinced reproductive activity. A Jaliscan female carried an embryo (crown-rump length, 13.5) on 20 May. Of 27 June-taken females from Sinaloa that were autopsied, 19 were pregnant and five were lactating; lactating females were obtained as late as 23 July when flying young of the year also were captured. Thirteen embryos examined in late June from the vicinity of Santa Lucía averaged 20.2 (14-30) in crown-rump length. Two August-taken males from Jalisco and one obtained on 10 December in Sinaloa had testes that measured 5, 8, and 4 , respectively.

Average and extreme external measurements for a series of 20 adult females from the vicinity of Santa Lucía, Sinaloa, followed by those for 20 adults (11 males, nine females) from southwest of Guadalajara, Jalisco, are as follows: 96.3 (92-101), 98.2 (89-105); 44.2 (41-49), 41.9 (40-45); 10.0 (9-11), $10.8(10-11) ; 15.8$ (15-17), 16.2 (15$18)$; 43.7 (41.6-45.3), 43.4 (40.7-46.1). Eleven nonpregnant Sinaloan females had an average weight of 8.9 (8.2-9.6). Specimens obtained in late spring and early summer are noticeably paler than those in fresh pelage taken later in the summer. Annual molt evidently takes place in late June and early July.

Myotis volans amotus Miller, 1914 ft., 3 .

Specimens examined.-JALISCO: $15 \mathrm{mi}$. S, $9 \mathrm{mi}$. E Talpa de Allende, 6900

This relatively rare southern subspecies of $M$. volans is reported in the literature only from the type locality in Veracruz and from two localities in southern Jalisco-Los Masos (Miller and Allen, 1928:145) and 8 mi. W Atenquique, at 9100 feet on the southeast slope of El Nevado de Colima (Baker and Phillips, 1965:691-692). Our specimens, the first from the mountains of northwestern Jalisco, were netted on 20 May 1964 over pools in a small stream that flowed through a valley cleared for grazing but surrounded by hills covered with pine and fir. Other species, all vespertilionids, taken in the same nets included Myotis velifer, Eptesicus fuscus, Lasiurus borealis, L. cinereus, and L. intermedius. Two of our three specimens are females and each carried an embryo (16, 18 in crown-rump length).

Among western Mexican members of the genus, $M . v$. amotus can be recognized easily by a combination of its relatively short and rounded ears, medium size (length of forearm, 38.8 to 39.5 in our three speci- 
ments), fur on the underside of the wing to the level of the elbow, ochraceous-tawny color, and high, rounded braincase. Baker and Phillips (loc. cit.) gave external and cranial measurements for a series from El Nevado de Colima.

Myotis yumanensis lutosus Miller and Allen, 1928

Specimens examined.-SINALOA: $1 / 2 \mathrm{mi}$. SE Vaca, $650 \mathrm{ft}$., $3 ; 6 \mathrm{~km}$. NE El Fuerte, 150 meters, 1 ; $2 \mathrm{mi}$. E Aguacaliente, $800 \mathrm{ft}$., 1; Cosalá, $1300 \mathrm{ft} ., 1$. JALISCO: Cuarenta, $6300 \mathrm{ft} ., 10$; El Salto, $24 \mathrm{mi}$. W Guadalajara, 1280 meters, 7; 2 mi. S La Cuesta, 1500 ft., 1.

The Yuma myotis evidently is widespread, albeit relatively rare or perhaps common only locally, in western México. Our specimens are the first of the species to be reported from Sinaloa and yumanensis was known previously from Jalisco only by two individuals of unknown provenience (Miller and Allen, 1928:72). Sinaloan specimens were netted or shot over streams bordered by deciduous trees, whereas those from Cuarenta, Jalisco, were shot from a night roost under a small bridge. Bats from El Salto, Jalisco, were netted, along with more than a dozen other species of chiropterans, over a wide, shallow stream bordered by dense trees that formed a canopy over it; relatively open grazed and farmed areas were adjacent to the stream.

We note a slight trend toward paler color northwardly, but no differences in size, in the specimens at hand. Along with a female from Vado Cuchijaqui, 9 mi. ESE Alamos, Sonora (KU 87126), all seem referable to a single subspecies, M. y. lutosus. Burt (1938:21) assigned specimens from eastern Sonora to the subspecies sociabilis because they were noticeably darker in color than $M . y$. yumanensis of adjacent regions to the north and the Mexican Plateau to the east. In so doing, he created a disjunct range for sociabilis (see Hall and Kelson, 1959:163) in that the Sonoran records were separated from the main range of the subspecies by a broad segment of the range of the pale race yumanensis. Burt did not consider the then poorly known lutosus in assigning his Sonoran material to sociabilis. We suspect that these specimens, like ours, are best assigned to lutosus, which evidently occupies west-central México and occurs also northward in the Sierra Madre Occidental and adjacent foothills to Sonora. Our material from northern Sinaloa and the one specimen from Sonora are intermediate in color between typical lutosus and Californian specimens of sociabilis, but nearer the former.

A female from Cosalá, Sinaloa (15 June 1962), carried an embryo that measured 14 in crown-rump length; two of four females taken on 14 August 1969 at El Salto, Jalisco, were lactating. Testes of males measured 3, 2, and 2 on 15 June, 14 August, and 24 November, respectively. 
External measurements of three males from northern Sinaloa, followed by the mean and extremes of those for six specimens (a male and five females) from El Salto, Jalisco, are: 74, 76, 78, 77.5 (75-82); 36, 30, 30, 35.0 (30-39); 8, 9, 9.5, 9.0 (8-10); 14, 14, 13.5, $13.6(13-14)$; $32.6,32.5,32.7,32.8(31.5-34.2)$; weight $3.7,4.6,4.0,3.7(2.6-4.6,5$ specimens only).

\section{Key to Western Mexican Myotis}

The following key is based on specimens examined by us and on meaurements and descriptions in the literature. It is devised to be as useful as possible in identifying specimens in the field. In addition to the characters used, the reader is directed to external measurements listed in the several accounts and to cranial measurements in Table 1.

1. Ear more than 15; forearm usually more than 39 ; greatest length of skull 16.0 or more; maxillary toothrow 6.2 or more

$1^{\prime}$. Ear 15 or (usually) less; forearm usually less than 39 (excepting $M$. volans); greatest length of skull 16.0 or less; maxillary toothrow 6.0 or less

2. Ear large, 18-20; color pale, ochraceous or tawny; breadth across upper molars 6.7 or less

2'. Ear medium, 15-18 (usually 16-17); color dark, grayish brown; breadth across upper molars 6.7 or (usually) more. Myotis velifer

3. Uropatagium with conspicuous fringe of hairs on posterior margin; forearm more than 42; membranes dark, contrasting with dorsum; length of maxillary toothrow less than breadth across upper molars

Myotis thysanodes

$3^{\prime}$. Uropatagium lacking conspicuous fringe of hairs on posterior margin; forearm less than 41 ; membranes pale, contrasting little with dorsum; length of maxillary toothrow greater than breadth across upper molars Myotis auriculus

4. Dorsum pale reddish or yellowish red; premolars $2 / 2$; greatest length of skull 14.4 or more Myotis fortidens

$4{ }^{\prime}$. Dorsum not pale reddish or yellowish red; premolars $3 / 3$; greatest length of skull 14.3 or less

5. Forearm more than 37; fur on underside of wing to level of elbow; breadth of braincase 7.0 or more Myotis volans

5'. Forearm less than 37; fur on underside of wing not extending to level of elbow; breadth of braincase 6.9 or less

6. Dorsum rich, dark brown to mahogany; ears and membranes blackish, ears opaque; hind foot small (usually 6-7), less than 50 per cent length of tibia measured dry; interorbital breadth 3.3 or (usually) less Myotis californicus

6 . Dorsum brownish; ears and membranes relatively pale, not contrasting noticeably with dorsum, ears translucent; hind foot medium (usually $8-9$ ), more than 50 per cent length of tibia measured dry; interorbital breadth 3.3 or more 
7. Venter grayish to whitish, occasionally with pale buffy wash; dorsum paler, brownish in fresh pelage, tips of hairs not noticeably burnished, bases dark grayish; breadth across upper molars 5.3 or less; length of maxillary toothrow 5.1 or less (averaging 4.9 ). Myotis yumanensis

7 '. Venter dark brown with distinctive buffy wash; dorsum darker, blackish brown in fresh pelage, tips of hairs burnished, bases dark brown to blackish; breadth across upper molars 5.4 or more; maxillary toothrow 5.1 or more (averaging 5.3) Myotis nigricans

\section{References}

Allen, J. A. 1890. Notes on collections of mammals made in central and southern Mexico, by Dr. Audley C. Buller, with descriptions of new species of the genera Vespertilio, Sciurus, and Lepus. Bull. Amer. Mus. Nat. Hist., 3:175-194.

Baker, R. H., and C. J. Phillips. 1965. Mammals from El Nevado de Colima, Mexico. Jour. Mamm., 46:691-693.

BURT, W. H. 1938. Faunal relationships and geographic distribution of mammals in Sonora, Mexico. Misc. Publ. Mus. Zool., Univ. Michigan, 39:1-77.

Davis, W. B., and D. C. Carter. 1962. Notes on Central American bats with description of a new subspecies of Mormoops. Southwestern Nat., 7:64-74.

FINDLEY, J. S. 1960. Identity of the long-eared myotis of the Southwest and Mexico. Jour. Mamm., 41:16-20.

FindLEY, I. S., and C. JoNES. 1967. Taxonomic relationships of bats of the species Myotis fortidens, M. lucifugus, and M. occultus. Jour. Mamm., 48:429-444.

GARDNER, A. L. 1962. Bat records from the Mexican states of Colima and Nayarit. Jour. Mamm., 43:102-103.

Genoways, H. H., and J. K. Jones, Jr. 1967. Notes on distribution and variation in the Mexican big-eared bat, Plecotus pbyllotis. Southwestern Nat., 12:477-480. . 1969. Taxonomic status of certain long-eared bats (genus Myotis) from the southwestern United States and Mexico. Southwestern Nat., $14: 1-13$.

Hall, E. R., and W. W. Dalquist. 1950. Pipistrellus cinnamomeus Miller 1902 referred to the genus Myotis. Univ. Kansas Publ., Mus. Nat. Hist., $1: 583-589$.

Hall, E. R., and K. R. Kelson. 1959. The mammals of North America. Ronald Press, New York, 1:xxx + 1-546 + 79.

HAYWARD, B. J. 1970. The natural history of the cave bat, Myotis velifer. Western New Mexico Univ. Res. Sci., 1:1-74.

Jones, J. K., JR. 1964. Bats from western and southern Mexico. Trans. Kansas Acad. Sci., 67:509-516.

Jones, J. K., JR., T. Alvarez, and M. R. Lee. 1962. Noteworthy mammals from Sinaloa, Mexico. Univ. Kansas Publ., Mus. Nat. Hist., 14:147159.

Miller, G. S., JR. 1897. Revision of the North American bats of the family Vespertilionidae. N. Amer. Fauna, 13:1-135.

Miller, G. S., JR., and G. M. Allen. 1928. The American bats of the genera Myotis and Pizonyx. Bull. U. S. Nat. Mus., 144:viii + 1-218.

Villa-R, B. 1967. Los murciélagos de México. Inst. Biol., Univ. México, xvi $+491 \mathrm{pp}$. 